\title{
Expression analysis of serum microRNAs in idiopathic pulmonary fibrosis
}

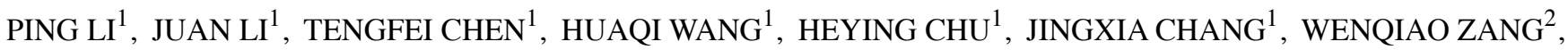 \\ YUANYUAN WANG ${ }^{2}$, YUNYUN MA ${ }^{2}$, YUWEN DU ${ }^{2}$, GUOQIANG ZHAO ${ }^{2}$ and GUOJUN ZHANG ${ }^{1}$ \\ ${ }^{1}$ Department of Respiratory Medicine, The First Affiliated Hospital of Zhengzhou University, Zhengzhou, \\ Henan 450052; ${ }^{2}$ Department of Microbiology and Immunology, College of Basic Medical Sciences, \\ Zhengzhou University, Zhengzhou, Henan 450001, P.R. China
}

Received December 8, 2013; Accepted March 18, 2014

DOI: $10.3892 /$ ijmm.2014.1712

\begin{abstract}
Idiopathic pulmonary fibrosis (IPF) is a disease of unknown etiology with considerable morbidity and mortality. Seeking informative diagnostic markers with greater clinical significance is essential for the early diagnosis of IPF. microRNAs (miRNAs or miRs) have emerged as novel serum diagnostic biomarkers for various diseases. In this study, we performed microarray analysis of the miRNA expression profile in the serum of patients with IPF compared to that of control subjects. We then performed a preliminary analysis of biological functions for the most differentially expressed miRNAs. Some of the microarray results were validated by quantitative reverse transcription-polymerase chain reaction (qRT-PCR). The results from this study provide evidence to link the biological role of miRNAs to IPF, and suggest that miRNAs may undertake a variety of functions. Additionally, we found that the altered expression levels of miR-21, miR-155 and $\mathrm{miR}-101-3 \mathrm{p}$ were associated with forced vital capacity (FVC) and radiological features in IPF. Our data may serve as a basis for further investigation, preferably in large prospective studies, before miRNA can be used as a non-invasive screening tool for IPF in routine clinical practice.
\end{abstract}

\section{Introduction}

Idiopathic pulmonary fibrosis (IPF) is a progressive interstitial lung disease of unknown etiology, with an appearance of usual

Correspondence to: Professor Guojun Zhang, Department of Respiratory Medicine, The First Affiliated Hospital of Zhengzhou University, 1 Jianshe East Road, Zhongyuan, Zhengzhou, Henan 450052, P.R. China

E-mail: gjzhangzzu@126.com

Professor Guoqiang Zhao, Department of Microbiology and Immunology, College of Basic Medical Sciences, Zhengzhou University, Zhengzhou, Henan 450001, P.R. China

E-mail: zhaogq@zzu.edu.cn

Key words: idiopathic pulmonary fibrosis, serum microRNA, microarray, quantitative reverse transcription-polymerase chain reaction interstitial pneumonia (UIP) on lung biopsy (1). Studies have indicated that the incidence of IPF is estimated to be 6.8 to 16.3 cases per 100,000 individuals each year in the United States, and the mean survival rate from the time of diagnosis is 3-5 years, regardless of treatment, which is a poorer prognosis than lung cancer (2-5). The distinct characteristics of IPF are identified through clinical manifestations, pulmonary function tests, radiology and prognosis. Currently, the diagnosis of IPF relies on the finding of lung mass in radiology imaging, mainly computed tomography (CT) and pulmonary function tests; however, the diagnosis of small lesions is relatively inaccurate. Currently, no known agents have been shown to reduce the mortality associated with IPF. Clinical trials are hindered by a dearth of clinically employed biomarkers, despite the establishment of some clinical characteristics and the fact that some peripheral blood proteins, such as the mucin-like glycoprotein, KL-6 (6), CC-chemokine ligand 18 (CCL-18) (7), surfactant protein A (SP)-A and D (SP-D) (8) and matrix metalloproteinase (MMP)-7 (9) are currently being investigated as potential biomarkers in patients with IPF. Therefore, seeking informative diagnostic markers with greater clinical significance is essential for the successful treatment and improved survival of patients with IPF.

microRNAs (miRNAs or miRs) are a novel class of naturally occurring, short, non-coding, single-stranded RNAs, that play key roles in various cellular processes commonly implicated in cancer, such as cell differentiation, cell growth, angiogenesis, epithelial-mesenchymal transition (EMT) and invasion (10-14). Following the release from apoptotic or necrotic cells as a result of tissue damage or chronic inflammation $(15,16)$, miRNAs are highly stable and abundant in biological fluids, such as blood, serum, plasma and cerebrospinal fluid (CSF) (17-20). With an increasing number of studies analyzing circulating miRNA expression profiles in plasma or serum, miRNAs have become an attractive source of new nucleic acid-based biomarkers. We previously demonstrated that miRNAs can be detected in the serum of patients with IPF (21). This finding raised the possibility that assaying miRNAs in serum may serve as a novel approach for the blood-based detection of IPF. In this study, we focused on the circulating miRNA expression profiles in serum samples of patienits with IPF, validated our microarray results 
through quantitative reverse transcription-polymerase chain reaction (qRT-PCR), and performed a preliminary analysis of the biological functions of the most differentially expressed miRNAs. These results may provide a basis for further study of the molecular markers associated with IPF for its early diagnosis.

\section{Materials and methods}

Clinical samples and serum collection. Following approval by the Ethics Committee of Zhengzhou University, Zhengzhou, China and after written informed consent was obtained, serum samples were collected from 149 subjects, including 76 patients with IPF and 73 age- and gender-matched healthy donors who served as the controls for this study. All samples were collected from consenting individuals at the First Affiliated Hospital of Zhengzhou University (FAHZZU). Patients were diagnosed with IPF using a multidisciplinary approach involving clinicians, radiologists and pathologists, along with high-resolution computed tomography (HRCT), and the relevant demographic and clinicopathological characteristics of the subjects were obtained. Control subjects were recruited from individuals who sought a routine health check-up at the Healthy Physical Examination Centre of FAHZZU.

For serum collection, venous blood ( $2 \mathrm{ml} / \mathrm{subject})$ was collected in the morning before breakfast from the patients with IPF and the control subjects, via a direct venous puncture, into tubes containing ethylenediaminetetraacetic acid (EDTA). The tubes were centrifuged at $2,500 \mathrm{x} \mathrm{g}$ for $10 \mathrm{~min}$ at $4^{\circ} \mathrm{C}$ to completely remove cellular components. Tthe serum was then collected gently and transferred into an RNase-free tube for the extraction of RNA and stored at $-80^{\circ} \mathrm{C}$.

RNA extraction. Total RNA, which included miRNAs, was isolated from the serum using a total RNA extraction kit (Shanghai Novland Co., Ltd., Shanghai, China) following the manufacturer's instructions. The quality of the total RNA was verified using a NanoDrop ND-1000 spectrophotometer (Thermo Scientific, Waltham, MA, USA). We defined an OD260/280 value of approximately 1.8 as a criterion of acceptable purity for further microarray analysis.

microRNA microarray analysis. To assess the labeling and hybridization efficiencies, the total RNA samples were spiked with the microRNA Spike-In kit (Agilent Technologies, Santa Clara, CA, USA). Following treatment with calf intestine phosphatase (CIP), a labeling reaction was initiated with $100 \mathrm{ng}$ of total RNA per sample. A T4 RNA ligase that incorporates cyanine 3-cytidine bisphosphate (miRNA Complete Labeling and Hyb kit; Agilent Technologies) was used to label the dephosphorylated RNA. The cyanine-3-labeled miRNA samples were then prepared for one-color-based hybridization (Complete miRNA Labeling and Hyb kit; Agilent Technologies). Hybridization was performed at $55^{\circ} \mathrm{C}$ for $20 \mathrm{~h}$ using a human miRNA microarray kit, Release 16.0, 8x60K format (Agilent Technologies). The microarray slides were washed (Gene Expression Wash Buffers; Agilent Technologies) and dried with acetonitrile (Sigma-Aldrich, St. Louis, MO, USA). Fluorescent signal intensities were detected using an Agilent DNA Microarray Scanner and Scan Control A.8.4.1 software (both from Agilent Technologies). The data were extracted using Feature Extraction 10.7.3.1 software (Agilent Technologies). Predicted target genes were analyzed with Gene Ontology (GO) enrichment analysis and Kyoto Encyclopedia of Genes and Genomes (KEGG) pathway mapping.

$q R T-P C R$. The microarray data was validated by qRT-PCR. U6 snRNA served as an endogenous control for normalization. A High-Specificity miRNA qRT-PCR Detection kit (Stratagene Corp., La Jolla, CA, USA) was used in conjunction with an ABI 7500 thermal cycler, according to the manufacturer's instructions. The correlating primers are shown in Table I. The PCR reaction was conducted at $95^{\circ} \mathrm{C}$ for $180 \mathrm{sec}$, followed by 40 cycles of $95^{\circ} \mathrm{C}$ for $15 \mathrm{sec}$ and $65^{\circ} \mathrm{C}$ for $30 \mathrm{sec}$. The results were analyzed using ABI Prism 7500 SDS software V1.3.1 (Applied Biosystems, Bedford, MA, USA) and expressed as relative quantification $\left(2^{-\Delta \mathrm{Ct}}\right)$ mode with triplicate measurements, as previously described (22), where the change in the threshold cycle $(\Delta \mathrm{Ct})=\mathrm{Ct}(\mathrm{miRNA})-\mathrm{Ct}$ (U6). Fold change values of the selected miRNAs were transformed to $\log 10$ values, both for the qRT-PCR and the microarray results.

Statistical analysis. SPSS version 17.0 software was used for statistical analysis (SPSS, Inc., Chicago, IL, USA). The difference in miRNA expression levels between 2 serum samples was determined by the Mann-Whitney U test. The Mann-Whitney U test and Kruskal-Wallis test were used to compare the differences among clinicopathological parameters. For multiple comparisons among groups (functional and radiographical variables), either one-way analysis of variance (ANOVA) followed by Tukey's test, or Kruskal-Wallis tests, where appropriate, were performed. A value of $\mathrm{P}<0.05$ was considered to indicate a statistically significant difference. Quantitative data are presented as the means \pm standard deviation (SD).

\section{Results}

Differential miRNA expression in serum from patients with $I P F$. Comparing the miRNA expression profiles in serum from patients with IPF and the healthy controls on the basis of the miRNA array results, we found that 60 miRNAs were differentially expressed in the serum of patients with IPF $(\mathrm{P}<0.05)$, including 8 upregulated and 52 downregulated miRNAs. Among the 60 differentially expressed miRNAs, all of the upregulated miRNAs (Table III) and 21 of the 52 downregulated miRNAs (Table II) showed at least a 2.5 -fold change in expression in the patients with IPF.

Relevant GO enrichment analysis of miRNAs in serum from patients with IPF. To determine the effects of the differentially expressed miRNAs on IPF and to better understand the functions of two types of genes in different biological processes, which provide more information on the miRNA expression profiles in serum from patients with IPF at the cellular level, we performed GO enrichment analysis with FunNet software. GO enrichment analysis includes molecular functions, cellular components and biological processes. The molecular functions of the upregulated genes identified by GO enrichment analysis included (among others) ligase activity, transporter 
Table I. List of primers used for qRT-PCR.

\begin{tabular}{|c|c|c|}
\hline Gene name & RT primers & PCR primers \\
\hline miR-101-3p & $\begin{array}{l}\text { 5'-GTCGTATCCAGTGCAGGGTCCGAGG } \\
\text { TATTCGCACTGGATACGACATGTCAT-3' }\end{array}$ & $\begin{array}{l}\text { F: 5'-TCCGAAAGTCAATAGTGTC-3' } \\
\text { R: 5'-GTGCAGGGTCCGAGGT-3' }\end{array}$ \\
\hline miR-142-5p & $\begin{array}{l}\text { 5'-GTCGTATCCAGTGCAGGGTCCGAGG } \\
\text { TATTCGCACTGGATACGACGTATTTC-3' }\end{array}$ & $\begin{array}{l}\text { F: 5'-TCCGATCATCACGAAAGAT-3' } \\
\text { R: 5'-GTGCAGGGTCCGAGGT-3' }\end{array}$ \\
\hline miR-557 & $\begin{array}{l}\text { 5'-GTCGTATCCAGTGCAGGGTCCGAGG } \\
\text { TATTCGCACTGGATACGACCAAACGT-3' }\end{array}$ & $\begin{array}{l}\text { F: 5'-TCCGATCTGTTCCGGGTGGGC-3' } \\
\text { R:5'-GTGCAGGGTCCGAGGT-3' }\end{array}$ \\
\hline miR-187-5p & $\begin{array}{l}\text { 5'-GTCGTATCCAGTGCAGGGTCCGAGG } \\
\text { TATTCGCACTGGATACGACCCGATGTT-3' }\end{array}$ & $\begin{array}{l}\text { F: 5'-TCCGACGGGCCCAGGACAC-3' } \\
\text { R: 5'-GTGCAGGGTCCGAGGT-3' }\end{array}$ \\
\hline miR-484 & $\begin{array}{l}\text { 5'-GTCGTATCCAGTGCAGGGTCCGAGG } \\
\text { TATTCGCACTGGATACGACAGTCCGAG-3' }\end{array}$ & $\begin{array}{l}\text { F: 5'-TCCGATAGCCCTCCCCTGA-3' } \\
\text { R: 5'-GTGCAGGGTCCGAGGT-3' }\end{array}$ \\
\hline $\operatorname{miR}-21$ & $\begin{array}{l}\text { 5'-GTCGTATCCAGTGCAGGGTCCGAGG } \\
\text { TATTCGCACTGGATACGACATCGAAT-3' }\end{array}$ & $\begin{array}{l}\text { F: 5'-TCCGAAGTTGTAGTCAGACT-3' } \\
\text { R: 5'-GTGCAGGGTCCGAGGT-3' }\end{array}$ \\
\hline miR-155 & $\begin{array}{l}\text { 5'-GTCGTATCCAGTGCAGGGTCCGAGG } \\
\text { TATTCGCACTGGATACGACAATTACG-3' }\end{array}$ & $\begin{array}{l}\text { F: 5'-TCCGATGGGGATAGTGCTAAT-3' } \\
\text { R: 5'-GTGCAGGGTCCGAGGT-3' }\end{array}$ \\
\hline miR-3675-3p & $\begin{array}{l}\text { 5'-GTCGTATCCAGTGCAGGGTCCGAGG } \\
\text { TATTCGCACTGGATACGACGTAGAGA-3' }\end{array}$ & $\begin{array}{l}\text { F: 5'-TCCGAAACCCCCTCAAGGAA-3' } \\
\text { R:5'-GTGCAGGGTCCGAGGT-3' }\end{array}$ \\
\hline $\operatorname{miR}-1229$ & $\begin{array}{l}\text { 5'-GTCGTATCCAGTGCAGGGTCCGAGG } \\
\text { TATTCGCACTGGATACGACGAGAGTG-3' }\end{array}$ & $\begin{array}{l}\text { F: 5'-TCCGAGACACCCTCCCGTCAC-3' } \\
\text { R:5'-GTGCAGGGTCCGAGGT-3' }\end{array}$ \\
\hline U6 snRNA & $\begin{array}{l}\text { 5'-GTCGTATCCAGTGCAGGGTCCGAGG } \\
\text { TATTCGCACTGGATACGACAAAATA-3' }\end{array}$ & $\begin{array}{l}\text { F: 5'-TCCGATCGTGAAGCGTTC-3' } \\
\text { R: 5'-GTGCAGGGTCCGAGGT-3' }\end{array}$ \\
\hline
\end{tabular}

qRT-PCR, quantitative reverse transcription-polymerase chain reaction.

Table II. Downregulated miRNAs with a $\geq 2.5$-fold change in expression in serum from patients with IPF.

\begin{tabular}{llll}
\hline Systematic name & \multicolumn{1}{c}{ FC } & \multicolumn{1}{c}{ Log FC } & Regulation \\
\hline hsa-miR-142-5p & -142.85098 & -7.158367 & Down \\
hsa-miR-3652 & -71.64325 & -6.162759 & Down \\
hsa-miR-4322 & -58.7685 & -5.8769712 & Down \\
hsa-miR-557 & -55.494648 & -5.7942767 & Down \\
hsa-miR-187-5p & -54.88799 & -5.7784185 & Down \\
hsa-miR-1224-5p & -51.036926 & -5.6734695 & Down \\
hsa-miR-484 & -49.851433 & -5.639563 & Down \\
hsa-miR-3682-3p & -48.302345 & -5.5940213 & Down \\
hsa-miR-3131 & -48.020832 & -5.5855885 & Down \\
hsa-miR-148b-3p & -47.77412 & -5.5781574 & Down \\
hsa-miR-874 & -44.02572 & -5.4602747 & Down \\
hsa-miR-150-5p & -42.34698 & -5.404187 & Down \\
hsa-miR-1305 & -41.710274 & -5.382331 & Down \\
hsa-miR-663a & -36.454872 & -5.18804 & Down \\
hsa-miR-101-3p & -34.896984 & -5.1250305 & Down \\
hsa-miR-516a-5p & -34.492382 & -5.108206 & Down \\
hsa-miR-328 & -33.15238 & -5.0510406 & Down \\
hsa-miR-877-5p & -32.35714 & -5.016012 & Down \\
hsa-miR-3137 & -31.168226 & -4.962004 & Down \\
hsa-miR-483-3p & -30.725616 & -4.94137 & Down \\
hsa-miR-23b-3p & -30.128986 & -4.91308 & Down \\
\hline
\end{tabular}

FC, fold change between IPF serum and healthy serum; miRNAs, microRNAs; IPF, idiopathic pulmonary fibrosis.
Table III. Upregulated miRNAs with a $\geq 2.5$-fold change in expression in serum from patients with IPF.

\begin{tabular}{lccc}
\hline Systematic name & FC & Log FC & Regulation \\
\hline hsa-miR-3675-3p & 74.52153 & 6.2195854 & Up \\
hsa-miR-21 & 54.23154 & 5.7234412 & Up \\
hsa-miR-1229 & 32.81375 & 5.0362287 & Up \\
hsa-miR-155 & 3.2157842 & 1.6084715 & Up \\
hsa-miR-18b-3p & 2.9419162 & 1.5567561 & Up \\
hsa-miR-636 & 2.8691778 & 1.5206374 & Up \\
hsa-miR-3646 & 2.8469105 & 1.5093971 & Up \\
hsa-miR-574-5p & 2.7281206 & 1.4479074 & Up \\
\hline
\end{tabular}

miRNAs, microRNAs; IPF, idiopathic pulmonary fibrosis; FC, fold change between IPF serum and healthy serum.

activity, signal transducer activity and actin binding, while the molecular functions of the downregulated genes included (among others) protein binding, mental ion binding, nucleotide binding, zinc ion binding, DNA binding and ATP binding (Fig. 1). The cellular components of the upregulated genes identified by GO enrichment analysis included (among others) the cytoplasm, cytoskeleton, synapses and cytoplasmic vesicles, while the cellular components of the downregulated genes included (among others) the nucleus, cytoplasm, cytosol and intracellular compartments (Fig. 2). The biological processes of the upregulated genes identified by GO enrichment analysis 


\section{GO Molecular Function}

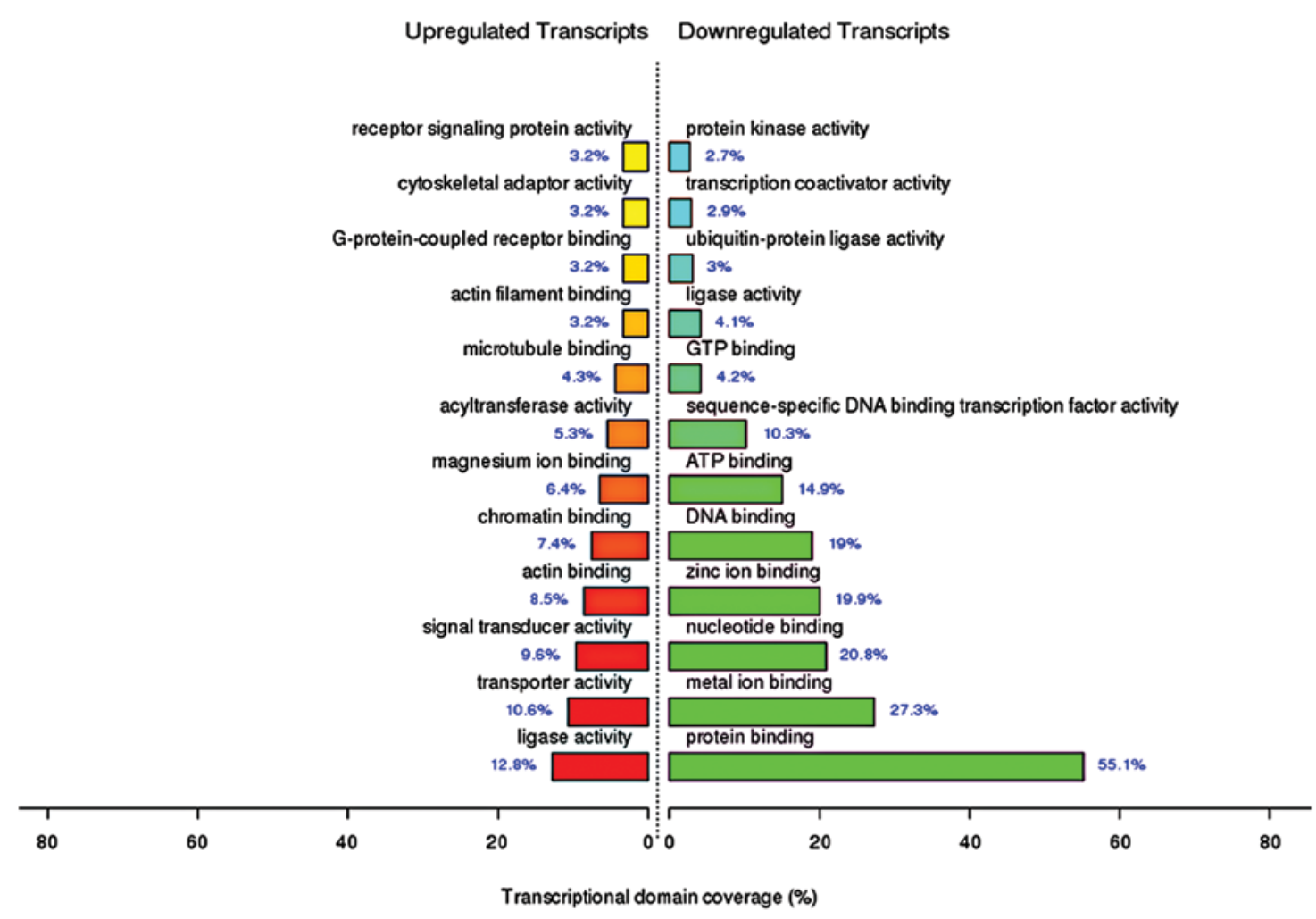

Figure 1. Molecular function of Gene Ontology (GO) enrichment analysis. GO enrichment was analyzed with FunNet software. GO molecular function includes the molecular functions of upregulated and downregulated genes.

\section{Go Cellular Component}

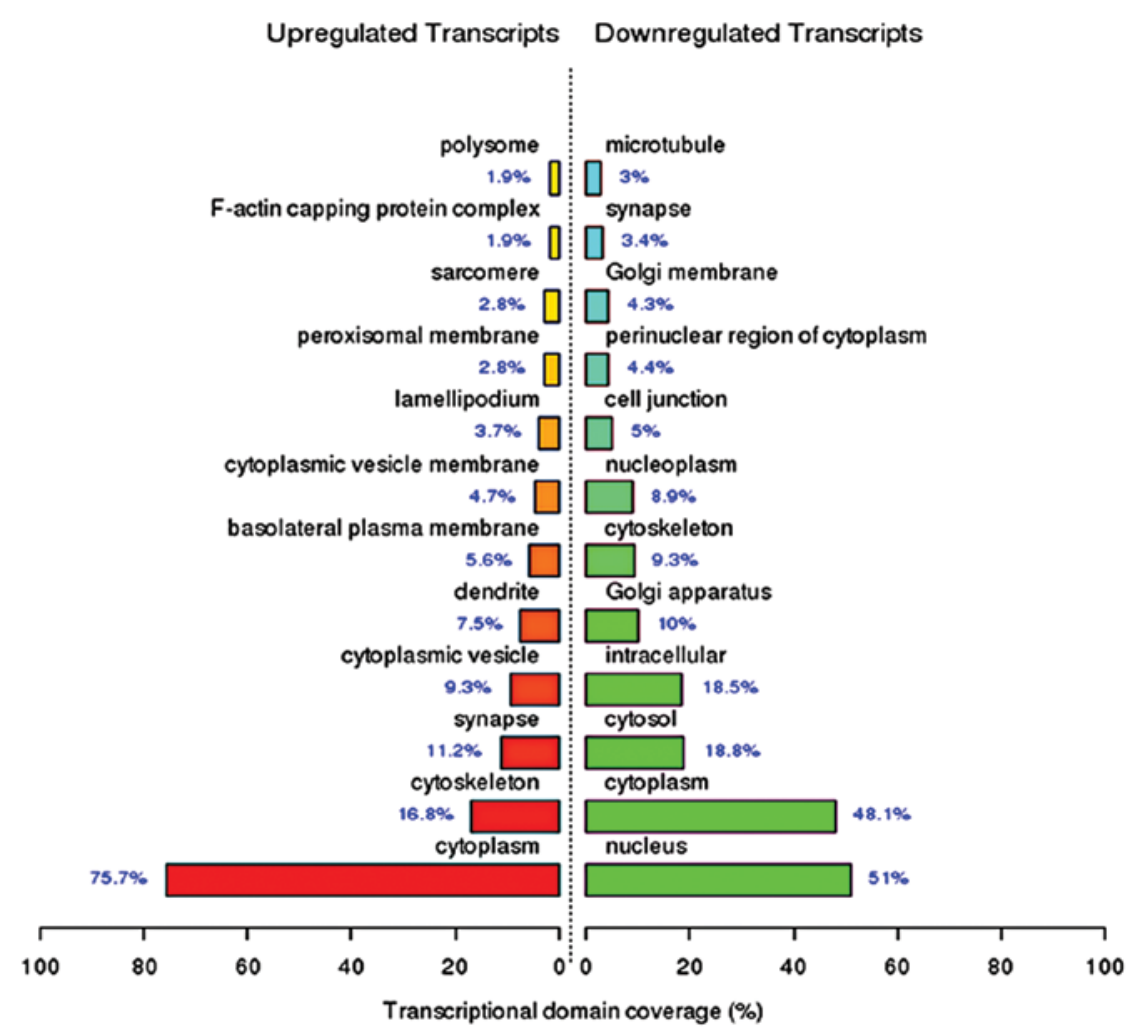

Figure 2. Cellular component of Gene Ontology (GO) enrichment analysis. GO enrichment was analyzed with FunNet software. GO cellular component includes cellular components of upregulated and downregulated genes. 


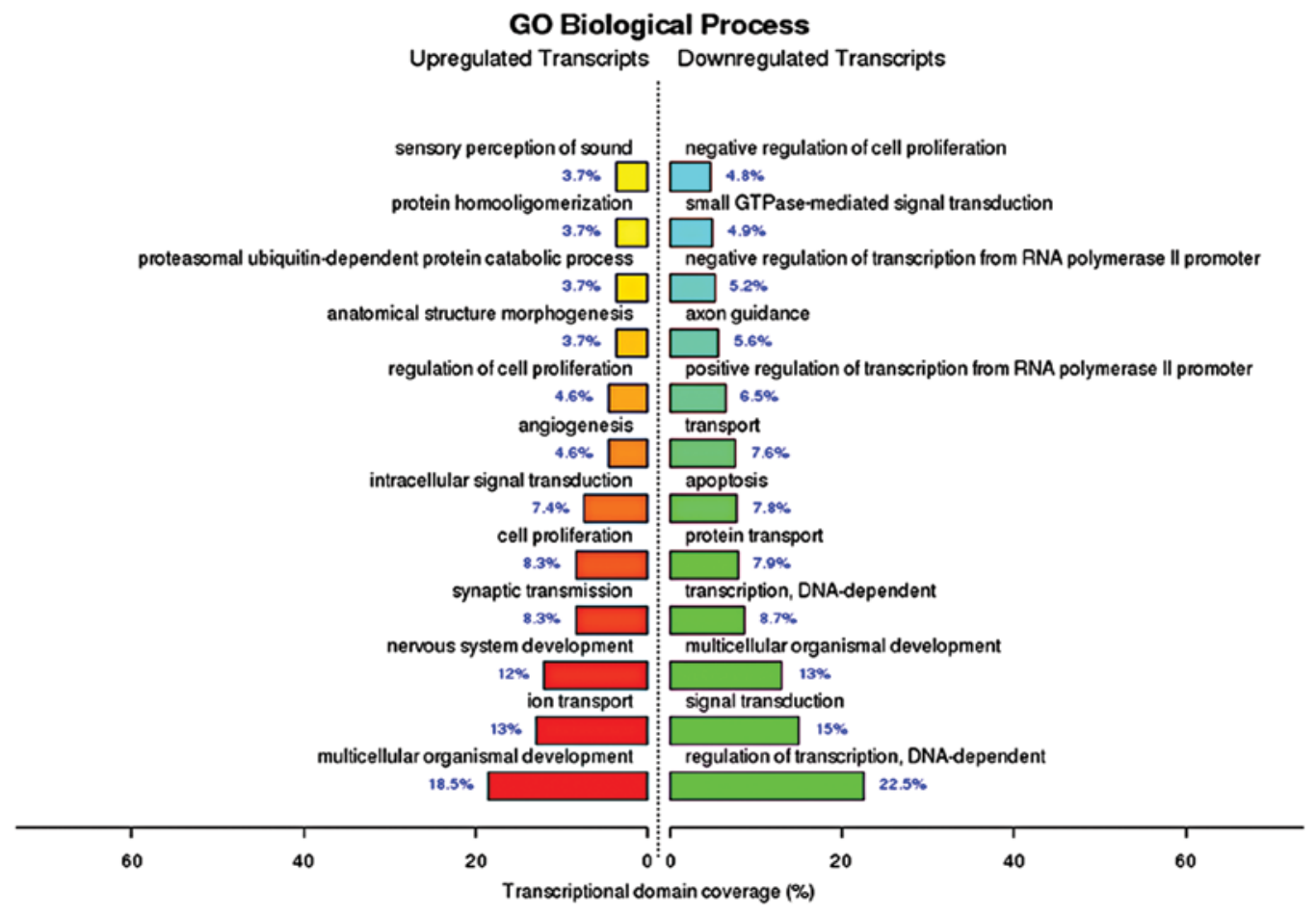

Figure 3. Biologyical process of Gene Ontology (GO) enrichment analysis. GO enrichment was analyzed with FunNet software. GO biologyical process includes biological processes of upregulated and downregulated genes.

included (among others) multicellular organismal development, ion transport and nervous system development, while the biological processes of the downregulated genes included (among others) the regulation of transcription, DNA-dependent signal transduction and multicellular organismal development (Fig. 3). All of the results showed that two types of genes exhibited variable distribution of some functions.

KEGG enrichment analysis of miRNAs in serum from patients with IPF. KEGG is a knowledge base for the systematic analysis of gene functions, in terms of the networks of genes and molecules. The major component of KEGG is the Pathway database, which consists of graphical diagrams of biochemical pathways including most of the known metabolic pathways and some of the known regulatory pathways. Upregulated transcripts included those involved in protein digestion and absorption, salivary secretion, acute myeloid leukemia, inositol phosphate metabolism, as well as others. Downregulated transcripts included those involved in cancer pathways, such as the regulation of the actin cytoskeleton, focal adhesion, protein processing in endoplasmic reticulum, as well as others (Fig. 4).

Validation of selected miRNA expression profiles in serum by $q R T-P C R$. On the basis of the microarray results, we selected 9 miRNAs, including 4 upregulated miRNAs (miR-3675-3p, miR-21, miR-1229 and miR-155) and 5 downregulated miRNAs (miR-142-5p, miR-557, miR-484, miR-187-5p and miR-101-3p) for further validation in IPF and in healthy serum by qRT-PCR. The expression of miR-142-5p, miR-557, miR-187-5p and miR-101-3p was found to be significantly reduced in the serum from patients with IPF $(\mathrm{P}<0.05)$. The expression of miR-3675-3p, miR-21 and miR-155 was found to be significantly increased in the serum of patients with IPF $(\mathrm{P}<0.05)$. However, the expression of miR-1229 and miR-187-5p did not differ significantly between the IPF and control serum samples $(\mathrm{P}>0.05)$. Generally, the results of the both methods (qRT-PCR and microarray) were quite similar (Fig. 5).

Expression levels of miRNAs in serum from patients with $I P F$ are associated with clinicopathologic characteristics of $I P F$. Combining the results of qRT-PCR and Agilent microarray, we found that the changes in the expression of miR-21 and miR-101-3p were more obvious than those of the other miRNAs. For all the samples, clinicopathological information (gender, age, FVC and HRCT) were available (Table IV). With further analysis, we also found that the expression levels of miR-21, miR-155 and miR-101-3p were associated with FVC and radiological features $(\mathrm{P}<0.05$ or $\mathrm{P}<0.01)$ (Table IV); however, no significant differences were observed between miR-21, miR-155 and miR-101-3p expression and gender and age $(\mathrm{P}>0.05)$ (Table IV).

\section{Discussion}

The diagnostic criteria for IPF are presented in the ATS/ERS statement (23). In the appropriate clinical setting, the presence of a UIP pattern on HRCT is sufficient for the diagnosis of IPF. However, some cases of UIP are difficult to differentiate from fibrotic non-specific interstitial pneumonia, which may exhibit honeycombing. Thus, the major and minor criteria for the clinical diagnosis of IPF have been eliminated in this new 
Table IV. miRNA expression levels associated with clinicopathological characteristics of patients with IPF.

\begin{tabular}{|c|c|c|c|c|c|c|c|}
\hline \multirow{2}{*}{$\begin{array}{l}\text { Clinicopathological } \\
\text { characteristic }\end{array}$} & \multirow[b]{2}{*}{$\mathrm{n}$} & \multicolumn{2}{|c|}{ miRNA-21 expression $\left(2^{-\Delta C t}\right)$} & \multicolumn{2}{|c|}{ miR-155 expression $\left(2^{-\Delta C t}\right)$} & \multicolumn{2}{|c|}{ miR-101-3p expression $\left(2^{-\Delta C t}\right)$} \\
\hline & & Median \pm SD & P-value & Median \pm SD & P-value & Median \pm SD & P-value \\
\hline Age (years) & & & 0.670 & & 0.509 & & 0.218 \\
\hline$>52$ & 37 & $4.33 \pm 3.44$ & & $3.70 \pm 4.65$ & & $0.89 \pm 1.17$ & \\
\hline$\leq 52$ & 39 & $3.88 \pm 2.64$ & & $2.89 \pm 3.95$ & & $0.78 \pm 0.43$ & \\
\hline Gender & & & 0.763 & & 0.597 & & 0.059 \\
\hline Male & 46 & $4.28 \pm 3.22$ & & $3.61 \pm 4.21$ & & $0.76 \pm 0.94$ & \\
\hline Female & 30 & $3.97 \pm 1.99$ & & $2.77 \pm 2.86$ & & $0.95 \pm 0.69$ & \\
\hline $\mathrm{FVC}(\%)$ & & & 0.016 & & 0.042 & & 0.037 \\
\hline Mild (80) & 18 & $2.20 \pm 0.98^{\mathrm{a}}$ & & $1.43 \pm 1.16^{\mathrm{a}}$ & & $1.21 \pm 1.43^{\mathrm{a}}$ & \\
\hline Moderate (50-80) & 22 & $3.45 \pm 2.89$ & & $2.70 \pm 2.70$ & & $0.95 \pm 0.88$ & \\
\hline Severe (50) & 36 & $4.60 \pm 3.36^{\mathrm{a}}$ & & $3.98 \pm 4.51^{\mathrm{a}}$ & & $0.57 \pm 0.40^{\mathrm{a}}$ & \\
\hline HRCT & & & 0.002 & & 0.005 & & 0.021 \\
\hline GGO & 17 & $1.90 \pm 0.78^{\mathrm{b}}$ & & $1.51 \pm 1.15^{\mathrm{b}}$ & & $1.17 \pm 1.04^{\mathrm{b}}$ & \\
\hline Reticulation & 26 & $3.20 \pm 2.13$ & & $2.57 \pm 2.68$ & & $0.92 \pm 0.80$ & \\
\hline Honeycombing & 33 & $4.72 \pm 3.43^{b}$ & & $4.79 \pm 4.71^{b}$ & & $0.59 \pm 0.34^{\mathrm{b}}$ & \\
\hline
\end{tabular}

${ }^{\mathrm{a}} \mathrm{P}<0.05 ;{ }^{\text {b }} \mathrm{P}<0.01$. FVC, forced vital capacity; HRCT, high resolution computed tomography; GGO, ground glass opacity; miRNAs, microRNAs; IPF, idiopathic pulmonary fibrosis; SD, standard deviation.

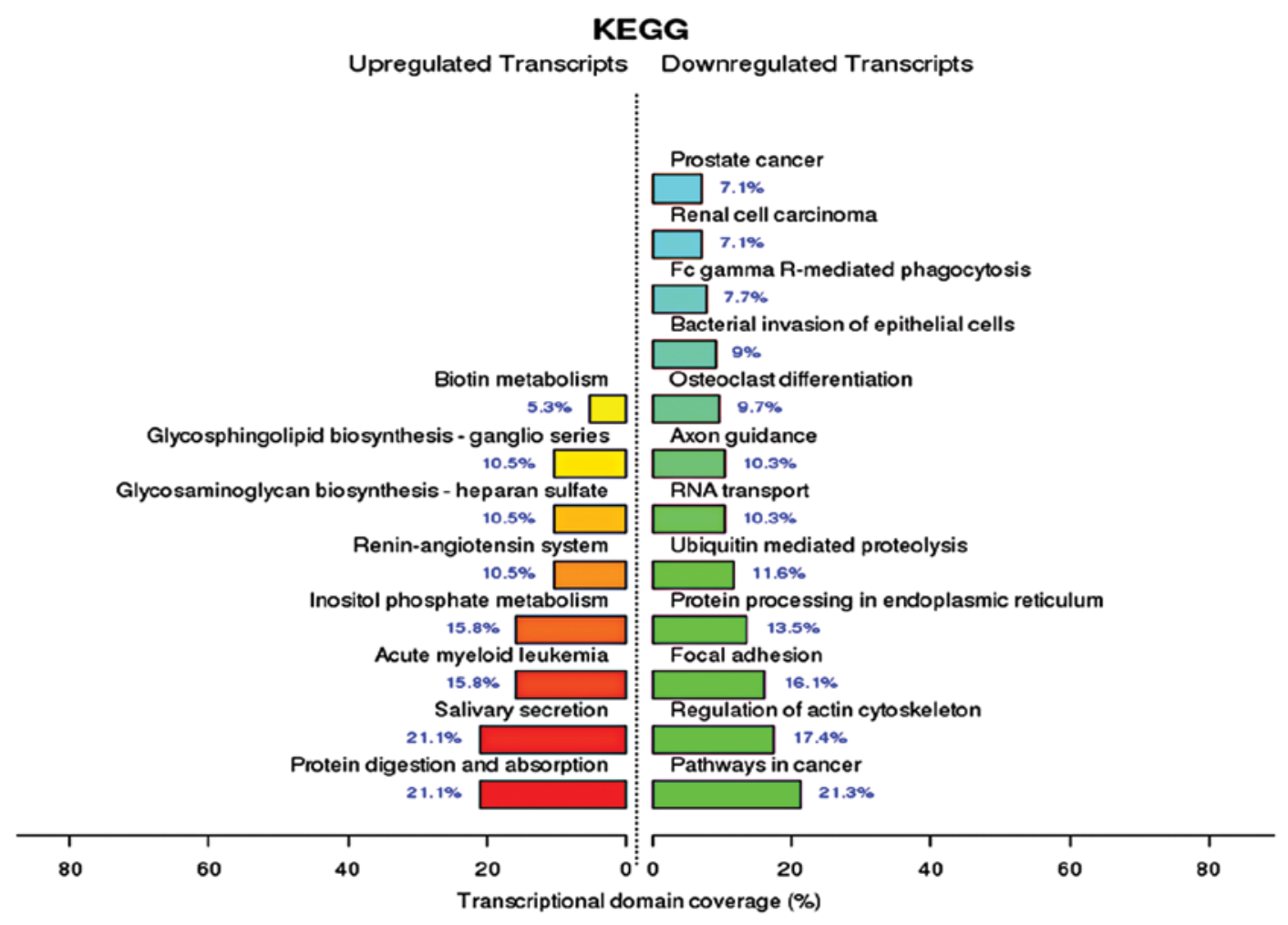

Figure 4. Kyoto Encyclopedia of Genes and Genomes (KEGG) enrichment analysis. KEGG enrichment was analyzed with FunNet software. KEGG Pathway database consists of graphical diagrams of biochemical pathways including most of the metabolic pathways and some of the regulatory pathways for the upregulated and downregulated genes.

ATS/ERS statement. The diagnosis of IPF can be achieved with certainty only after the pulmonologist, radiologist and pathologist have reviewed all of the clinical, radiological and pathological data. 

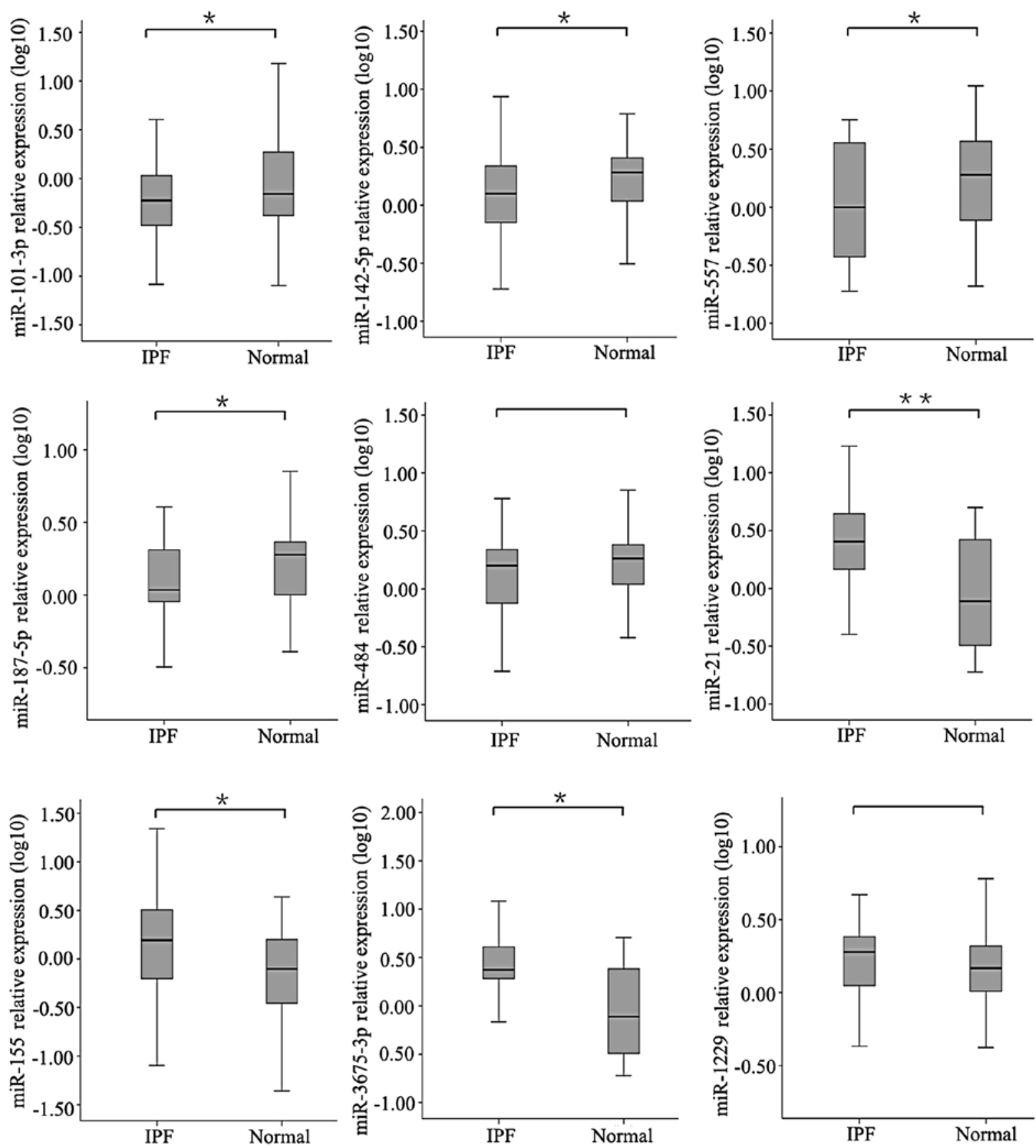

Figure 5. The microarray results of 9 miRNAs were validated by performing quantitative RT-PCR. The relative expression levels of 4 upregulated miRNAs and 5 downregulated miRNAs in serum from patients with idiopathic pulmonary fibrosis (IPF) and healthy controls were determined by qRT-PCR. Compared with healthy serum, miR-3675-3p, miR-21 and miR-155 expression levels in serum from patients with IPF were significantly higher. The relative expression levels of miR-142-5p, miR-557, miR-187-5p and miR-101-3p in serum from patients with IPF were significantly lower ("P<0.05 and $\left.{ }^{* *} \mathrm{P}<0.01\right)$. miR-1229 and miR-484 were not matched $(\mathrm{P}>0.05)$.

Increasing evidence indicates that serum miRNAs may offer an interesting new avenue for diagnostic development in a variety of diseases. In the field of cancer, miR-21 was the first serum miRNA to be identified, and was associated with large B-cell lymphoma (24). Serum miRNAs have also been suggested to be novel biomarkers for ovarian cancer $(25)$, lung cancer $(26,27)$ and colorectal cancer (28). Furthermore, miRNAs have been implicated as circulating biomarkers in tissue injury, including liver, muscle and brain $(29,30)$. The interest in serum miRNAs lies in their central roles in the regulation of gene expression and the implication of miRNA-specific aberrant expression in the pathogenesis of a number of diseases.

In the present study, we obtained a total of 76 serum samples from patients with IPF to study changes in miRNA expression compared to serum samples obtained from healthy subjects. The microarray data showed that 60 important miRNAs were differentially expressed in patients with IPF. The varying expression of miRNAs provides a useful clue for the in-depth research of serological diagnosis in IPF. With the results of microarray analysis, we selected 9 miRNAs 
that exhibited marked variations in expression for validation by qRT-PCR, including 4 upregulated miRNAs and 5 downregulated miRNAs. We found that the qRT-PCR and Agilent microarray miRNA profiles significantly correlated. Among the 9 miRNAs examined, miR-3675-3p, miR-21, miR-155, miR-142-5p, miR-557, miR-187-5p and miR-101-3p showed significant changes in expression $(\mathrm{P}<0.05)$. We also found that the expression of miR-21 was markedly altered, and that the upregulation of miR-21 was consistent with its expression level in IPF tissue, as previously demonstrated (31). These observations demonstrate the importance of investigating the roles of the remaining miRNAs in the pathogenesis of IPF and analyzing the biologically relevant molecular mechanisms in future studies. Furthermore, the specific functions of serum miRNAs, such as those identified by GO enrichment and KEGG enrichment analysis, may also provide some guidance for further verification through functional studies, which may have ties with the biological processes of IPF at the cellular level. Additionally, we demonstrated that the expression levels of miR-21, miR-155 and miR-101-3p in serum were associated with the degree of FVC and HRCT in IPF. However, no correlation was observed between these miRNAs and other clinicopathological characteristics, including gender and age. These findings suggest that miR-21, miR-155 and miR-101-3p play an important role in the progression and development of IPF. Multi-analysis showed that serum miRNA expression levels were the potential prognostic factors for patients with IPF. Of course, more extensive data and studies with a larger sample number are required to confirm the diagnostic significance of miRNA expression levels in patients with IPF.

In conclusion, our study established differential expression profiles of miRNAs, which seem to be involved in different biological processes in IPF. Additionally, we found that the altered expression levels of miR-21, miR-155 and miR-101-3p were associated with the degree of FVC and HRCT in IPF. Our data may serve as a basis for further investigation, preferably in large prospective studies, before miRNAs can be used as a non-invasive screening tool for IPF in routine clinical practice.

\section{Acknowledgements}

The authors are grateful to all staff at the study centre who contributed to this study. This study was supported by a grant from the Ministry of Major Science and Technology of Henan (20130205).

\section{References}

1. Maher TM, Wells AU and Laurent GJ: Idiopathic pulmonary fibrosis: multiple causes and multiple mechanisms? Eur Respir J 30: 835-839, 2007.

2. Fernández Pérez ER, Daniels CE, Schroeder DR, St Sauver J, Hartman TE, Bartholmai BJ, Yi ES and Ryu JH: Incidence, prevalence, and clinical course of idiopathic pulmonary fibrosis: a population-based study. Chest 137: 129-137, 2010.

3. Navaratnam V, Fleming KM, West J, Smith CJ, Jenkins RG, Fogarty A and Hubbard RB: The rising incidence of idiopathic pulmonary fibrosis in the U.K. Thorax 66: 462-467, 2011.

4. Nalysnyk L, Cid-Ruzafa J, Rotella P and Esser D: Incidence and prevalence of idiopathic pulmonary fibrosis: review of the literature. Eur Respir Rev 21: 355-361, 2012.

5. Ley B, Collard HR and King TE Jr: Clinical course and prediction of survival in idiopathic pulmonary fibrosis. Am J Respir Crit Care Med 183: 431-440, 2011.
6. Yokoyama A, Kondo K, Nakajima M, Matsushima T, Takahashi T, Nishimura M, Bando M, Sugiyama Y, Totani Y, Ishizaki T, Ichiyasu H, Suga M, Hamada $\mathrm{H}$ and Kohno N: Prognostic value of circulating KL-6 in idiopathic pulmonary fibrosis. Respirology 11: 164-168, 2006.

7. Prasse A, Probst C, Bargagli E, Zissel G, Toews GB, Flaherty KR, Olschewski M, Rottoli P and Muller-Quernheim J: Serum CC-chemokine ligand 18 concentration predicts outcome in idiopathic pulmonary fibrosis. Am J Respir Crit Care Med 179: 717-723, 2009.

8. Kinder BW, Brown KK, McCormack FX, Ix JH, Kervitsky A, Schwarz MI and King TE Jr: Serum surfactant protein-A is a strong predictor of early mortality in idiopathic pulmonary fibrosis. Chest 135: 1557-1563, 2009.

9. Rosas IO, Richards TJ, Konishi K, Zhang Y, Gibson K, Lokshin AE, Lindell KO, Cisneros J, Macdonald SD, Pardo A, Sciurba F, Dauber J, Selman M, Gochuico BR and Kaminski N: MMP1 and MMP7 as potential peripheral blood biomarkers in idiopathic pulmonary fibrosis. PLoS Med 5: e93, 2008.

10. Lin KY, Zhang XJ, Feng DD, Zhang H, Zeng CW, Han BW, Zhou AD, Qu LH, Xu L and Chen YQ: miR-125b, a target of CDX2, regulates cell differentiation through repression of the core binding factor in hematopoietic malignancies. J Biol Chem 286: 38253-38263, 2011.

11. Han BW, Feng DD, Li ZG, Luo XQ, Zhang H, Li XJ, Zhang XJ, Zheng LL, Zeng CW, Lin KY, Zhang P, Xu L and Chen YQ: A set of miRNAs that involve in the pathways of drug resistance and leukemic stem-cell differentiation is associated with the risk of relapse and glucocorticoid response in childhood ALL. Hum Mol Genet 20: 4903-4915, 2011.

12. Hwang MS, Yu N, Stinson SY, Yue P, Newman RJ, Allan BB and Dornan D: miR-221/222 targets adiponectin receptor 1 to promote the epithelial-to-mesenchymal transition in breast cancer. PLoS One 8: e66502, 2013.

13. Paterson EL, Kazenwadel J, Bert AG, Khew-Goodall Y, Ruszkiewicz A and Goodall GJ: Down-regulation of the miRNA-200 family at the invasive front of colorectal cancers with degraded basement membrane indicates EMT is involved in cancer progression. Neoplasia 15: 180-191, 2013.

14. Cheng CW, Wang HW, Chang CW, Chu HW, Chen CY, Yu JC, Chao JI, Liu HF, Ding SL and Shen CY: MicroRNA-30a inhibits cell migration and invasion by downregulating vimentin expression and is a potential prognostic marker in breast cancer. Breast Cancer Res Treat 134: 1081-1093, 2012.

15. Bala S, Tilahun Y, Taha O, Alao H, Kodys K, Catalano D and Szabo G: Increased microRNA-155 expression in the serum and peripheral monocytes in chronic HCV infection. J Transl Med 10: 151, 2012

16. van der Meer AJ, Farid WR, Sonneveld MJ, de Ruiter PE, Boonstra A, van Vuuren AJ, Verheij J, Hansen BE, de Knegt RJ, van der Laan LJ and Janssen HL: Sensitive detection of hepatocellular injury in chronic hepatitis $\mathrm{C}$ patients with circulating hepatocyte-derived microRNA-122. J Viral Hepat 20: 158-166, 2013.

17. Haghikia A, Haghikia A, Hellwig K, Baraniskin A, Holzmann A, Décard BF, Thum $\mathrm{T}$ and Gold R: Regulated microRNAs in the CSF of patients with multiple sclerosis: a case-control study. Neurology 79: 2166-2170, 2012.

18. Mitchell PS1, Parkin RK, Kroh EM, Fritz BR, Wyman SK, Pogosova-Agadjanyan EL, Peterson A, Noteboom J, O'Briant KC, Allen A, Lin DW, Urban N, Drescher CW, Knudsen BS, Stirewalt DL, Gentleman R, Vessella RL, Nelson PS, Martin DB and Tewari M: Circulating microRNAs as stable blood-based markers for cancer detection. Proc Natl Acad Sci USA 105: 10513-10518, 2008.

19. Liu R, Chen X, Du Y, Yao W, Shen L, Wang C, Hu Z, Zhuang R, Ning G, Zhang C, Yuan Y, Li Z, Zen K, Ba Y and Zhang CY: Serum microRNA expression profile as a biomarker in the diagnosis and prognosis of pancreatic cancer. Clin Chem 58: 610-618, 2012.

20. Yang C, Wang C, Chen X, Chen S, Zhang Y, Zhi F, Wang J, Li L, Zhou X, Li N, Pan H, Zhang J, Zen K, Zhang CY and Zhang C: Identification of seven serum microRNAs from a genome-wide serum microRNA expression profile as potential noninvasive biomarkers for malignant astrocytomas. Int J Cancer 132: 116-127, 2013.

21. Li P, Zhao GQ, Chen TF, Chang JX, Wang HQ, Chen SS and Zhang GJ: Serum miR-21 and miR-155 expression in idiopathic pulmonary fibrosis. J Asthma 50: 960-964, 2013. 
22. Schmittgen TD and Livak KJ: Analyzing real-time PCR data by the comparative C(T) method. Nat Protoc 3: 1101-1108, 2008.

23. Raghu G, Collard HR, Egan JJ, et al: An official ATS/ERS/JRS/ ALAT statement: idiopathic pulmonary fibrosis: evidence-based guidelines for diagnosis and management. Am J Respir Crit Care Med 183: 788-824, 2011.

24. Lawrie CH, Gal S, Dunlop HM, Pushkaran B, Liggins AP, Pulford K, Banham AH, Pezzella F, Boultwood J, Wainscoat JS, Hatton CS and Harris AL: Detection of elevated levels of tumour-associated microRNAs in serum of patients with diffuse large B-cell lymphoma. Br J Haematol 141: 672-675, 2008.

25. Zheng H, Zhang L, Zhao Y, Yang D, Song F, Wen Y, Hao Q, Hu Z, Zhang $\mathrm{W}$ and Chen K: Plasma miRNAs as diagnostic and prognostic biomarkers for ovarian cancer. PLoS One 8: e77853, 2013.

26. Liu XG, Zhu WY, Huang YY, Ma LN, Zhou SQ, Wang YK, Zeng F, Zhou JH and Zhang YK: High expression of serum miR-21 and tumor miR-200c associated with poor prognosis in patients with lung cancer. Med Oncol 29: 618-626, 2012.

27. Wang Y, Gu J, Roth JA, Hildebrandt MA, Lippman SM, Ye Y, Minna JD and Wu X: Pathway-based serum microRNA profiling and survival in patients with advanced stage non-small cell lung cancer. Cancer Res 73: 4801-4809, 2013.
28. Wang Q, Huang Z, Ni S, Xiao X, Xu Q, Wang L, Huang D, Tan C, Sheng W and Du X: Plasma miR-601 and miR-760 are novel biomarkers for the early detection of colorectal cancer. PLoS One 7: e44398, 2012.

29. Laterza OF, Lim L, Garrett-Engele PW, Vlasakova K, Muniappa N, Tanaka WK, Johnson JM, Sina JF, Fare TL, Sistare FD and Glaab WE: Plasma MicroRNAs as sensitive and specific biomarkers of tissue injury. Clin Chem 55: 1977-1983, 2009.

30. Tryndyak VP, Latendresse JR, Montgomery B, Ross SA, Beland FA, Rusyn I and Pogribny IP: Plasma microRNAs are sensitive indicators of inter-strain differences in the severity of liver injury induced in mice by a choline- and folate-deficient diet. Toxicol Appl Pharmacol 262: 52-59, 2012.

31. Liu G, Friggeri A, Yang Y, Milosevic J, Ding Q, Thannickal VJ, Kaminski $\mathrm{N}$ and Abraham E: miR-21 mediates fibrogenic activation of pulmonary fibroblasts and lung fibrosis. J Exp Med 207: $1589-1597,2010$ 